\title{
Comparison of flexural strength according to thickness between CAD/CAM denture base resins and conventional denture base resins
}

\author{
Dong-Hyung Lee, Joon-Seok Lee* \\ Department of Prosthodontics, College of Dentistry, Dankook University, Cheonan, Republic of Korea
}

\begin{abstract}
Purpose: The purpose of this study is to compare the flexural strength of CAD/CAM denture base resins with conventional denture base resins based on their thicknesses. Materials and Methods: For the conventional denture base resins, Lucitone $199{ }^{\circledR}$ (C-LC) was used. DIOnavi - Denture (P-DO) and DENTCA Denture Base II (P-DC) were taken for the 3D printing denture base resins. For the prepolymerized PMMA resins, Vipi Block Gum (M-VP) and M-IVoBase ${ }^{\circledR}$ CAD (M-IV) were used. The final dimensions of the specimens were $65.0 \mathrm{~mm} \times 12.7 \mathrm{~mm} \times 1.6 \mathrm{~mm} / 2.0 \mathrm{~mm} / 2.5 \mathrm{~mm}$. The 3-point bend test was implemented to measure the flexural strength and flexural modulus. Microscopic evaluation of surface of fractured specimen was conducted by using a scanning electron microscope (SEM). After testing the normality of the data, one-way ANOVA was adopted to evaluate the differences among sample groups with a significance level of $P=0.05$. The Tukey HSD test was performed for post hoc analysis. Results: Under the same thicknesses, there are significant differences in flexural strength between CAD/CAM denture base resins and conventional denture base resins except for P-DO and C-LC. M-VP showed higher flexural strength than conventional denture base resins, P-DC and M-IV displayed lower flexural strength than conventional denture base resins. Flexural modulus was highest in M-VP, followed by C-LC, P-DO, P-DC, $\mathrm{M}-\mathrm{IV}$, significant differences were found between all materials. In the comparison of flexural strength according to thickness, flexural strength of $2.5 \mathrm{~mm}$ was significantly higher than that of $1.6 \mathrm{~mm}$ in C-LC. Flexural strength of $2.5 \mathrm{~mm}$ and $2.0 \mathrm{~mm}$ was significantly higher than that of $1.6 \mathrm{~mm}$ in P-DC and M-VP. In M-IV, as the thickness increases, significant increase in flexural strength appeared. SEM analysis illustrates different fracture surfaces of the specimens. Conclusion: The flexural strength of different CAD/CAM denture base resins used in this study varied according to the composition and properties of each material. The flexural strength of CAD/ CAM denture base resins was higher than the standard suggested by ISO 20795-1:2013 at a thickness of 1.6 mm or more though the thickness decreased. However, for clinical use of dentures with lower thickness, further researches should be done regarding other properties at lower thickness of denture base resins. (J Dent Rehabil Appl Sci 2020;36(3):183-95)
\end{abstract}

Key words: CAD/CAM denture base resins; pre-polymerized PMMA block; 3D printing denture base resins; flexural strength; thickness

\section{Introduction}

Polymethyl methacrylate (PMMA) resin became one of the most commonly used dental materials since it was introduced in the $1930 \mathrm{~s}^{1,2}$ Denture

\footnotetext{
*Correspondence to: Joon-Seok Lee

Professor, Department of Prosthodontics, College of Dentistry, Dankook University, Dandae-ro 119, Dongnam-gu, Cheonan, Choongnam, 31116, Republic of Korea Tel: +82-41-550-0256, Fax: +82-41-550-1975, E-mail: joon322@dankook.ac.kr Received: July 22, 2020/Last Revision: August 6, 2020/Accepted: August 31, 2020
}

resins should have sufficient strength and toughness to ensure dimensional stability under various temperature conditions of intraoral environment for decades. ${ }^{1-3}$ Nonetheless, denture fracture has been reported continuously as the main cause of denture

Copyright@ 2020 The Korean Academy of Stomatognathic Function and Occlusion. (c) It is identical to Creative Commons Non-Commercial License. 
treatment failures. ${ }^{4}$ According to Zarb et al. ${ }^{1} 68$ percent of acrylic dentures were broken within a couple of years after their delivery. This result implies that denture fracture is one of the most common failures of denture treatment. ${ }^{5}$ Therefore many attempts have been made to enhance mechanical properties of denture base resins by mixing additives to change microstructure and by increasing the ratio of fluid/ powder. ${ }^{6-9}$ Additionally, various producing methods have been introduced to simplify the polymerization process and to strengthen the physical properties of dentures. $^{10,11}$

Denture bases are repeatedly subjected to bending force caused by bite force applied over the years resulting in fracture or crack of denture bases. ${ }^{12}$ Furthermore, the unevenly distributed stresses in denture occurred by the irregular absorption of alveolar ridges contribute to the denture fracture. ${ }^{13}$ Therefore, sufficient strength and toughness are needed to ensure that denture bases to endure the stress when they function in the oral environment. A high degree of flexural strength is required to prevent fracture of denture since the flexural strength represents the maximum bending stress of the material at the moment of fracture. ${ }^{14,15}$ Based on American Society for Testing and Materials (ASTM) D790 that complies with the standard of ISO 20795-1:2013 for the denture base polymer. ${ }^{16-18} 3$-point bend test which can evaluate strength and resistance of the material is recommended to estimate the flexural strength of denture base resins. ${ }^{16-18}$

With the development of Computer-Aided Design/Computer Aided-Manufacturing (CAD/CAM) technique, the complete denture manufacturing based on the CAD/CAM system is actively being performed. ${ }^{19,20}$ Many clinical researches have reported that they made dentures with CAD/CAM technique, which cuts off the resin blocks by milling or with 3D printing which reduces the polymerization contraction. These works are to overcome the problems of the conventional denture base resins that accompany the contraction and warp issues during the polymerization. $^{21,22}$ The resin blocks for milling are industrially fabricated under high temperature and pressure. Accordingly, they are highly condensed and have less fine porosity, which leads to little polymerization contraction during the manufacturing process, ensuring less residual monomers. ${ }^{23}$ Due to these attributes, the companies that manufacture CAD/CAM denture base resins argue that $\mathrm{CAD} / \mathrm{CAM}$ denture base resins have better mechanical properties than the conventional denture base resins. ${ }^{24}$ Therefore, the dentures with thinner thickness and enhanced density may be possible, making patients more satisfied. ${ }^{24}$ However, there are few researches about the mechanical properties of CAD/CAM denture base resins compared to the conventional denture base resins. Also, it is barely possible to find research that examines the flexural strength of denture base resins according to different thicknesses.

Therefore, the main purpose of this study is to compare flexural strength and flexural modulus of $\mathrm{CAD} / \mathrm{CAM}$ denture base resins with conventional denture base resins based on different thicknesses. The null hypotheses were set as follows.

1. The flexural strength and flexural modulus of CAD/CAM denture base resins P-DO not have significant differences with those of conventional denture base resins.

2. As the thickness of denture base resins reduces, the flexural strength of denture bases resins decreases significantly.

\section{Materials and Methods}

This study used one type of conventional denture base resin, two types of $3 \mathrm{D}$ printing denture base resins and two types of CAD/CAM denture base resins for milling. The information regarding the five different types of denture base resins adopted in this study is described in the Table 1. All materials complied with the standards of ISO 20795-1:2013 (Dentistry-Base polymers - Part 1: Denture base polymers). ${ }^{18}$

\section{Fabrication of specimens}

The materials were divided into three groups with different thicknesses: $1.6 \mathrm{~mm}, 2.0 \mathrm{~mm}, 2.5 \mathrm{~mm}$. The lengths between supports of each thicknesses were 
Table 1. Compositions and manufacturers' specifications of tested materials

\begin{tabular}{cccc}
\hline Product Name & Manufacturer & Head Office & Composition \\
\hline Lucitone $199^{\circledR}$ & Dentsply Sirona Inc. & York, PA, USA & Methyl Methacrylate \\
DIOnavi - Denture & DIO IMPLANT CO. & Busan, Korea & $\begin{array}{c}\text { Methacrylic oligomers } \\
\text { Phosphine oxides }\end{array}$ \\
DENTCA - Denture Base II & DENTCA, Inc. & Torrance, CA, USA & $\begin{array}{c}\text { Methacrylate monomer } \\
\text { Diurethane dimethacrylate }\end{array}$ \\
Vipi Block Gum & VIPI Industria & São Paulo, Brazil & Methyl Methacrylate \\
Ivobase $^{\circledR}$ CAD & Ivoclar Vivadent Inc. & Schaan, Liechtenstein & Methyl Methacrylate \\
\hline
\end{tabular}

Table 2. Abbreviations of tested material groups

\begin{tabular}{ccccc}
\hline Material & Abbreviation & Groups $(\mathrm{n}=10)$ & $2.5 \mathrm{~mm}$ \\
\hline Lucitone $199^{\circledR}$ & C-LC & C-LC1 & C-LC2 & C-LC3 \\
DIOnavi - Denture & P-DO & P-DO1 & P-DO2 & P-DO3 \\
DENTCA - Denture Base II & P-DC & P-DC1 & P-DC2 & P-DC3 \\
Vipi Block Gum & M-VP & M-VP1 & M-VP2 & M-VP3 \\
Ivobase $^{\circledR}$ CAD & M-IV & M-IV1 & M-IV2 & M-IV3 \\
\hline
\end{tabular}

$25.6 \mathrm{~mm}$ (thickness $1.6 \mathrm{~mm}$ ), $32.0 \mathrm{~mm}$ (thickness 2.0 $\mathrm{mm}$ ), $40.0 \mathrm{~mm}$ (thickness $2.5 \mathrm{~mm}$ ). The width of the specimen was $12.7 \mathrm{~mm}(1 / 2$ inch) and the length of each edge of the specimen was $65.0 \mathrm{~mm}$. In this study, 150 rectangle shaped specimens were used, 15 subgroups were set depending on the materials and thickness. The number of specimens of each subgroup was designed to be 10 . Table 2 summarizes the abbreviations of each material and the subgroups by different thickness.

To fabricate specimens for the conventional denture base resins, pink base-plate wax was flasked and invested using ISO type 3 dental stone (Microstone, Whip Mix Co, Louisville, USA) according to the manufacturer's instruction. Then the flasks were heated for 8 minutes and detached. The waxes were washed with clean water and the flaskes were cooled to the room temperature. When the denture base resin, Lucitone $199^{\circledR}$ (Dentsply Sirona, York, USA), reached the dough stage the resins were condensed by figure pressure. Then the flasks were closed using flask press (OL57, MANFREDI, Torino, Italy) applying the pressure up to $45 \mathrm{kgf} / \mathrm{cm}^{2}$. The flasks were fixed into a spring clamp and put into a polymeriza- tion unit (Hanau Curing Unit, Hanau Engineering Company Inc., Buffalo, USA). Then, the flasks were heated for 1 hour 30 minutes at $73^{\circ} \mathrm{C}$ and another 30 minutes at $100^{\circ} \mathrm{C}$ according to the manufacturer instructions. After the flasks were pulled out from the polymerization unit, the flasks were cooled to the room temperature for 30 minutes and immersed in $21^{\circ} \mathrm{C}$ water for 15 minutes. After unboxing the investment box, the cuboid shape specimens were cut by a slicing machine (Samsung Clover, Seoul, Korea) with a diamond disk and ground by a grinding machine (SPL-15 Grind X; OKAMOTO Co., Tokyo, Japan) to meet the final dimensions. Finally, the specimens were cleansed by an ultrasonic device (SD-120H, Mujigae Co., Seoul, Korea) and washed in distilled water.

The specimens for 3D printing denture base resins were produced by requesting standard tessellation language (STL) files from DENTCA ${ }^{\text {TM }}$ CAD/CAM DENTURE (DENTCA - Denture Base II, DENTCA Inc., Torrance, USA) and DIO (DIOnavi - Denture; DIO IMPLANT CO., LTD, Busan, Korea). After fabrication, it was confirmed that the specimens meet the final dimensions. 
Vipi Block Gum (VIPI Industria, São Paulo, Brazil) and IvoBase ${ }^{\circledR}$ CAD (Ivoclar Vivadent Inc., Schaan, Liechtenstein) were used as CAD/CAM denture base resin blocks for milling. The resin blocks were cut with the slicing machine (Samsung Clover) using the diamond disk and ground by the grinding machine (SPL-15 Grind X, OKAMOTO Co.) to achieve the final dimension. The specimens were cleaned by an ultrasonic device (SD-120H, Mujigae Co.) and washed in distilled water.

All specimens were evaluated to investigate any voids or irregularities. Based on the standard of ISO 20795-1:2013, the specimens were polished with the 500-grit, 1000-grit and 1500-grit abrasive papers (DAESUNG, Incheon, Korea) under water cooling. Then the specimens were measured using the digital caliper (IP65; Mitutoyo, Kawasaki, Japan) at 5 different parts within $0.01 \mathrm{~mm}$ error range. Before a 3 -point bend test, all specimens were stored in distilled water at $37^{\circ} \mathrm{C}$ temperature for 50 hours.

\section{3-point bend test and scanning electron microscope (SEM) analysis}

The 3-point bend test was conducted based on the standard of ASTM D790. ${ }^{19}$ In this study, a universal testing machine (QM100TS Universal Testing Machine, Instron Ltd, Norwood, USA) was used. Specimens were laid on supports with a diameter of 5.0 $\mathrm{mm}$ and the middle part of specimens were pressed at a crosshead speed of $5 \mathrm{~mm} / \mathrm{min}$. The experiment was continued until the specimens fractured. The strength and the modulus of elasticity were measured using a software program MC_Tester Version 12.1.0 (Universal Testing Machine of Software, Instron Ltd). The maximum strength was recorded with Newton's (N) measurement and the modulus of elasticity was calculated automatically by using the linear of the stress-strain curve in the software program. Additionally, the transformation of the specimen $(\mathrm{mm})$ and the following stress $(\mathrm{N})$ is measured. The flexural strength and flexural modulus were calculated by the following equations: Flexural strength $(\mathrm{MPa})=3 \mathrm{PL} / 2 \mathrm{bd}^{2}$, Flexural modulus $(\mathrm{MPa})=$ $\mathrm{L}^{3} \mathrm{~m} / 4 \mathrm{bd}^{3}$. In this equation, $\mathrm{P}=$ maximum strength
$(\mathrm{N}), \mathrm{L}=$ length of support fixtures $(\mathrm{mm}), \mathrm{b}=$ width of specimen $(12.7 \mathrm{~mm}), \mathrm{d}=$ thickness of specimen $(1.6,2.0,2.5 \mathrm{~mm}), \mathrm{m}=$ gradient of the initial linear of the stress-strain curve $\left(\mathrm{N} / \mathrm{mm}^{2}\right)$

Two samples were randomly selected from each groups and executed a surface analysis for the fractured section of specimens by using a SEM $(\times 500, \times$ 1000 magnification) (ZEISS GeminiSEM 500, Carl Zeiss Co., Oberkochen, Germany).

\section{Statistical analysis}

The analysis was conducted by using SPSS (v23.0, IBM Co., Armonk, USA) software program. A normality test was implemented with a KolmogorovSmirnov test and One-way analysis of variance (ANOVA) was used to evaluate differences between groups. Tukey HSD test was used for post-hoc analysis $(P=0.05)$.

\section{Results}

Table 3 describes the average values and standard deviations of the flexural strength of each group. Table 4 shows the average values and standard deviations of the flexural modulus of each group.

Within all thicknesses, M-VP shows the highest average for flexural strength. The average flexural strength of P-DO is not significantly different from that of C-LC. P-DC and M-IV show lower average flexural strength compared to C-LC $(P<0.001)$. P-DO has higher flexural strength compared to the other 3D printing denture resin $(P<0.001)$, P-DC. The post-hoc analysis results are presented in Table 5 and Fig. 1.

The average flexural moduli under the same thickness were significantly different among the materials except for the comparison between P-DC and M-IV at the thickness of $2.5 \mathrm{~mm}$. M-VP showed the highest average flexural modulus. C-LC, P-DO, P-DC and M-IV follows the next accordingly. The post-hoc analysis results are summarized in Table 6 and Fig. 2.

As the thickness increases, the average flexural strength is also increased in each group. However significant differences were not found all the time. 
Table 3. Means and standard deviations of flexural strength in all groups

\begin{tabular}{cccccc}
\hline \multirow{2}{*}{ Thickness } & C-LC & P-DO & Mean \pm SD (MPa) & M-VP & M-IV \\
\hline $1.6 \mathrm{~mm}$ & $92.34 \pm 3.19$ & $95.39 \pm 3.89$ & $66.27 \pm 6.07$ & $102.47 \pm 7.05$ & $76.38 \pm 4.54$ \\
$2.0 \mathrm{~mm}$ & $95.24 \pm 3.62$ & $95.53 \pm 4.89$ & $80.02 \pm 5.53$ & $110.06 \pm 2.69$ & $85.27 \pm 2.87$ \\
$2.5 \mathrm{~mm}$ & $97.01 \pm 2.36$ & $97.96 \pm 3.04$ & $82.15 \pm 1.32$ & $111.35 \pm 2.59$ & $92.04 \pm 3.34$ \\
\hline
\end{tabular}

C-LC, Lucitone $199^{\circledR}$; P-DO, DIOnavi - Denture; P-DC, DENTCA - Denture Base II; M-VP, Vipi Block Gum; M-IV, Ivobase ${ }^{\circledR}$ CAD

Table 4. Means and standard deviations of flexural modulus in all groups

\begin{tabular}{|c|c|c|c|c|c|}
\hline \multirow{2}{*}{ Thickness } & \multicolumn{5}{|c|}{ Mean $\pm \mathrm{SD}(\mathrm{MPa})$} \\
\hline & C-LC & P-DO & P-DC & M-VP & M-IV \\
\hline $1.6 \mathrm{~mm}$ & $2705.4 \pm 273.58$ & $2382.57 \pm 107.99$ & $1907.87 \pm 233.26$ & $3252.42 \pm 88.57$ & $1396.39 \pm 109.86$ \\
\hline $2.0 \mathrm{~mm}$ & $2706.93 \pm 50.45$ & $2427.36 \pm 144.59$ & $2131 \pm 114.02$ & $3259.86 \pm 15.42$ & $1842.74 \pm 59.06$ \\
\hline $2.5 \mathrm{~mm}$ & $2774.99 \pm 40.98$ & $2550.82 \pm 112.58$ & $2157.61 \pm 64.06$ & $3213.76 \pm 14.77$ & $2090.74 \pm 29.78$ \\
\hline
\end{tabular}

C-LC, Lucitone $199^{\circledR}$; P-DO, DIOnavi - Denture; P-DC, DENTCA - Denture Base II; M-VP, Vipi Block Gum; M-IV, Ivobase ${ }^{\circledR}$ CAD

Under the group of C-LC, the significant differences were only found under the thicknesses of $1.6 \mathrm{~mm}$ and $2.5 \mathrm{~mm}(P=.006)$. In the group of P-DO, there was no significant difference in the flexural strength depending on the changes in thickness. The P-DC and M-VP groups showed significant differences between $1.6 \mathrm{~mm}$ and $2.0 \mathrm{~mm}(P<0.001, P=0.003)$ as well as between $1.6 \mathrm{~mm}$ and $2.5 \mathrm{~mm}(P<0.001)$. The group of M-IV showed significant differences across all thicknesses $(P<0.001)$. The post-hoc analysis results are described in Fig. 3.

The images of SEM (Fig. 4 and 5) illustrate differences in the surface structure of each denture resin. M-VP had a relatively smooth and even surface. The surfaces of C-LC, P-DO, P-DC and M-IV were noticeably rough and showed various coarse mass forming stripes. Notably, the surface of M-IV showed a considerable amount of white spherical particles that are likely to contain various microspheres.

\section{Discussion}

The size of specimens used in this study did not coincide with the standard size for a 3-point bend test suggested by ISO 20795-1:2013. When the size of the specimen changes, it is reasonable to follow the ASTM D790 international standard. ${ }^{17}$ The reason that the minimum thickness was set to be $1.6 \mathrm{~mm}$ $(1 / 16$ inch) is that if the thickness of the specimen becomes thinner than $1.6 \mathrm{~mm}(1 / 16 \mathrm{inch})$, then the length and width of the specimen should be changed accordingly. Thus, to keep the consistency in dimensions of the specimens with the other thickness groups, $1.6 \mathrm{~mm}$ was set to be the minimum thickness. As mentioned in ASTM D790, the most critical factor to reduce errors by conducting a 3-point bend test is the ratio between the length of the support beams and the thickness of the specimen, which is 16. Accordingly, $25.6 \mathrm{~mm}, 32.0 \mathrm{~mm}$ and $40.0 \mathrm{~mm}$ were set as the lengths of support beams. In addition to this, ASTM D790 defines that if the thickness of the specimen is thinner than $3.2 \mathrm{~mm}(1 / 8$ inch $)$ and thicker than $1.6 \mathrm{~mm}$ (1/16 inch), then the width of the specimen should be $12.7 \mathrm{~mm}$ (1/2 inch). Also, the lengths of the specimen's edges should be either at least 10 percent of the whole length of support beams or $6.4 \mathrm{~mm}$ (1/4 inch) to prevent the specimen from slipping into the support beam. Therefore, the final dimensions were designed to be $65.0 \mathrm{~mm} \times$ $12.7 \mathrm{~mm} \times 1.6 \mathrm{~mm} / 2.0 \mathrm{~mm} / 2.5 \mathrm{~mm}$.

According to the results from this study, the first null hypothesis was partially rejected. Furthermore, 


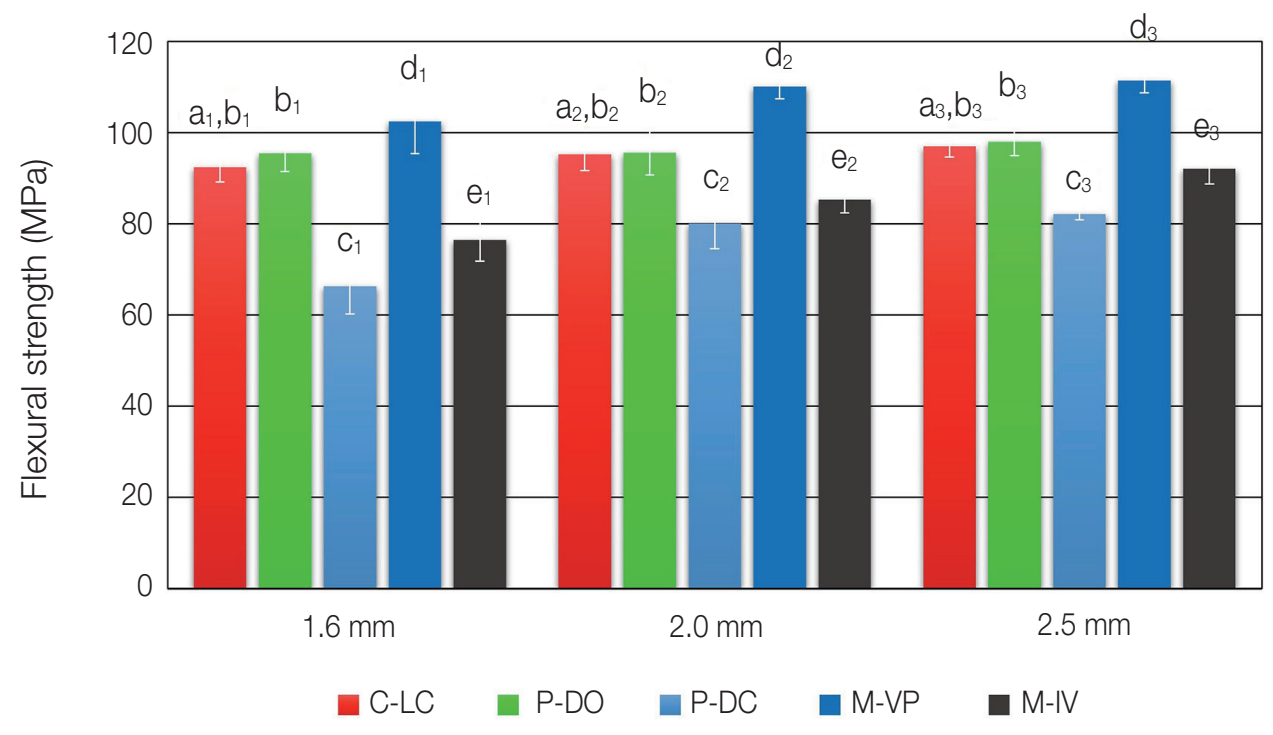

Fig. 1. Mean flexural strength of the different materials in the same thickness. Different single letters denote statistical difference. C-LC, Lucitone 199 ${ }^{\circledR}$; P-DO, DIOnavi- Denture; P-DC, DENTCA- Denture Base II; M-VP, Vipi Block Gum; M-IV, M-IVobase ${ }^{\circledR}$ CAD.

Table 5. Tukey HSD test of flexural strength between groups in $1.6 \mathrm{~mm}, 2.0 \mathrm{~mm}$ and $2.5 \mathrm{~mm}$ thickness

\begin{tabular}{|c|c|c|c|c|c|c|}
\hline \multirow{2}{*}{ Thickness } & \multicolumn{6}{|c|}{$P$ value } \\
\hline & & C-LC & P-DO & P-DC & M-VP & M-IV \\
\hline \multirow{5}{*}{$1.6 \mathrm{~mm}$} & C-LC & & 0.676 & $<0.001 *$ & $0.001 *$ & $<0.001^{*}$ \\
\hline & P-DO & & & $<0.001 *$ & $0.029 *$ & $<0.001^{*}$ \\
\hline & P-DC & & & & $<0.001 *$ & $0.001 *$ \\
\hline & M-VP & & & & & $<0.001^{*}$ \\
\hline & M-IV & & & & & \\
\hline \multirow{5}{*}{$2.0 \mathrm{~mm}$} & C-LC & & 1.000 & $<0.001 *$ & $<0.001 *$ & $<0.001 *$ \\
\hline & P-DO & & & $<0.001 *$ & $<0.001 *$ & $<0.001^{*}$ \\
\hline & P-DC & & & & $<0.001^{*}$ & $0.046^{*}$ \\
\hline & $\mathrm{M}-\mathrm{VP}$ & & & & & $<0.001^{*}$ \\
\hline & M-IV & & & & & \\
\hline \multirow{5}{*}{$2.5 \mathrm{~mm}$} & C-LC & & 0.926 & $<0.001 *$ & $<0.001 *$ & $0.001 *$ \\
\hline & P-DO & & & $<0.001 *$ & $<0.001^{*}$ & $<0.001^{*}$ \\
\hline & P-DC & & & & $<0.001 *$ & $<0.001^{*}$ \\
\hline & $M-V P$ & & & & & $<0.001^{*}$ \\
\hline & M-IV & & & & & \\
\hline
\end{tabular}

C-LC, Lucitone $199^{\circledR}$; P-DO, DIOnavi - Denture; P-DC, DENTCA - Denture Base II; M-VP, Vipi Block Gum; M-IV, Ivobase ${ }^{\circledR}$ CAD. 


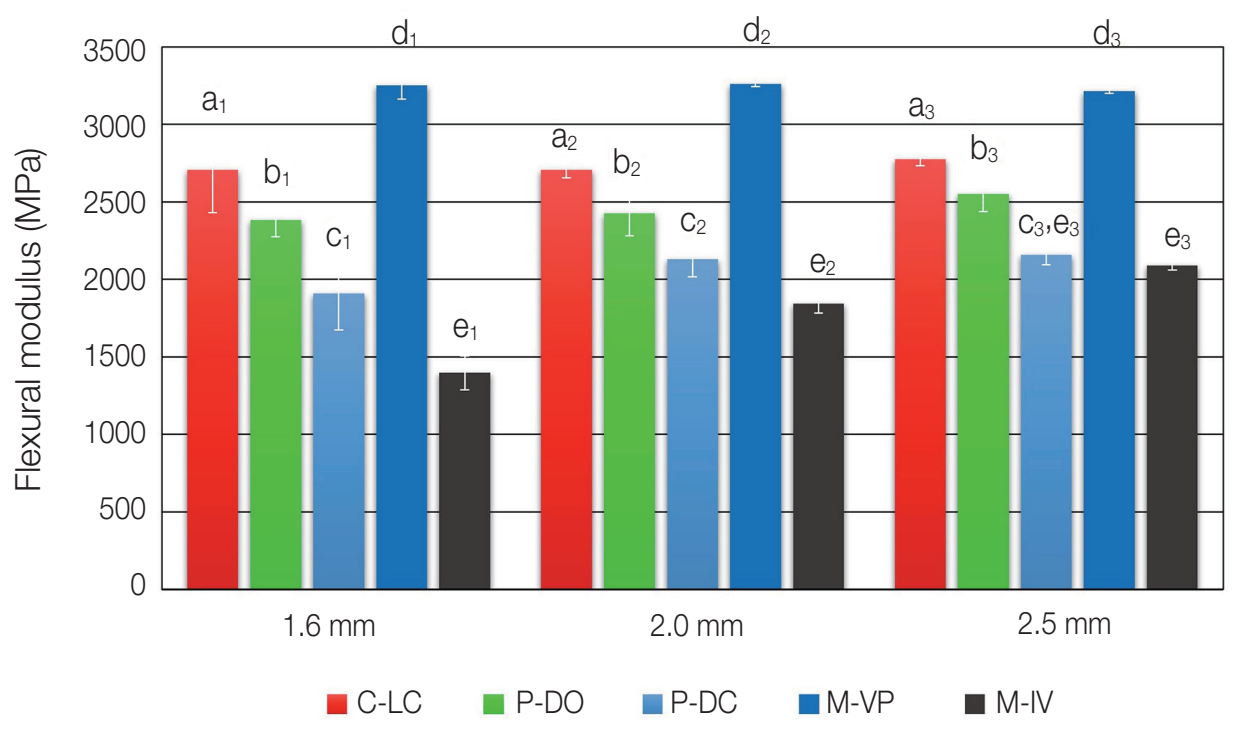

Fig. 2. Mean flexural modulus of the different materials in the same thickness. Different single letters denote statistical difference. C-LC, Lucitone 199 ${ }^{\circledR}$; P-DO, DIOnavi- Denture; P-DC, DENTCA- Denture Base II; M-VP, Vipi Block Gum; M-IV, M-IVobase ${ }^{\circledR}$ CAD.

Table 6. Tukey HSD test of flexural modulus between groups in $1.6 \mathrm{~mm}, 2.0 \mathrm{~mm}$ and $2.5 \mathrm{~mm}$ thickness

\begin{tabular}{|c|c|c|c|c|c|c|}
\hline \multirow{2}{*}{ Thickness } & \multicolumn{6}{|c|}{$P$ value } \\
\hline & & C-LC & P-DO & P-DC & M-VP & M-IV \\
\hline \multirow{5}{*}{$1.6 \mathrm{~mm}$} & C-LC & & $0.002 *$ & $<0.001 *$ & $<0.001 *$ & $<0.001^{*}$ \\
\hline & P-DO & & & $<0.001 *$ & $<0.001 *$ & $<0.001^{*}$ \\
\hline & P-DC & & & & $<0.001 *$ & $0.001^{*}$ \\
\hline & M-VP & & & & & $<0.001 *$ \\
\hline & M-IV & & & & & \\
\hline \multirow{5}{*}{$2.0 \mathrm{~mm}$} & C-LC & & $<0.001 *$ & $<0.001 *$ & $<0.001 *$ & $<0.001 *$ \\
\hline & P-DO & & & $<0.001 *$ & $<0.001 *$ & $<0.001^{*}$ \\
\hline & P-DC & & & & $<0.001^{*}$ & $0.001 *$ \\
\hline & M-VP & & & & & $<0.001 *$ \\
\hline & M-IV & & & & & \\
\hline \multirow{5}{*}{$2.5 \mathrm{~mm}$} & C-LC & & $<0.001 *$ & $<0.001 *$ & $<0.001 *$ & $0.001 *$ \\
\hline & P-DO & & & $<0.001 *$ & $<0.001 *$ & $<0.001 *$ \\
\hline & P-DC & & & & $<0.001 *$ & 0.137 \\
\hline & M-VP & & & & & $<0.001 *$ \\
\hline & M-IV & & & & & \\
\hline
\end{tabular}

C-LC, Lucitone $199^{\circledR}$; P-DO, DIOnavi - Denture; P-DC, DENTCA - Denture Base II; M-VP, Vipi Block Gum; M-IV, Ivobase ${ }^{\circledR}$ CAD. 


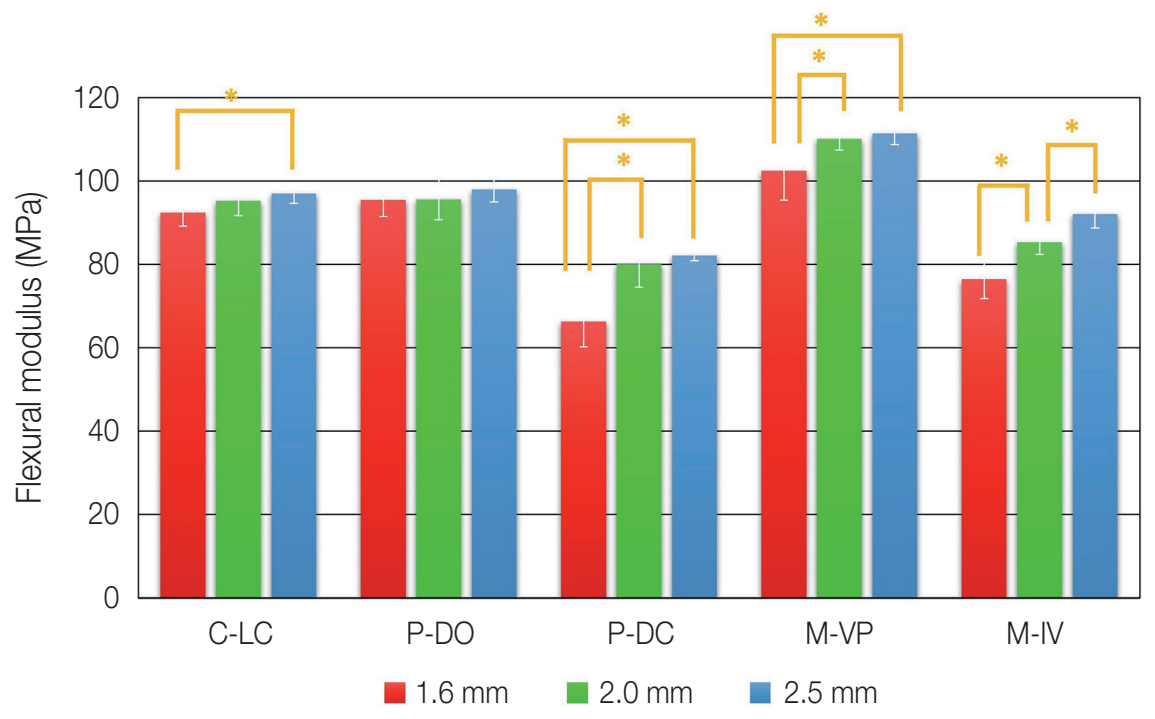

Fig. 3. Mean flexural strength of the different thickness in the same materials. ${ }^{*}$ denotes significant difference at the level of 0.05. C-LC, Lucitone 199® ${ }^{\circledR}$; P-DO, DIOnavi- Denture; P-DC, DENTCA- Denture Base II; M-VP, Vipi Block Gum; M-IV, M-Ivobase ${ }^{\circledR}$ CAD.
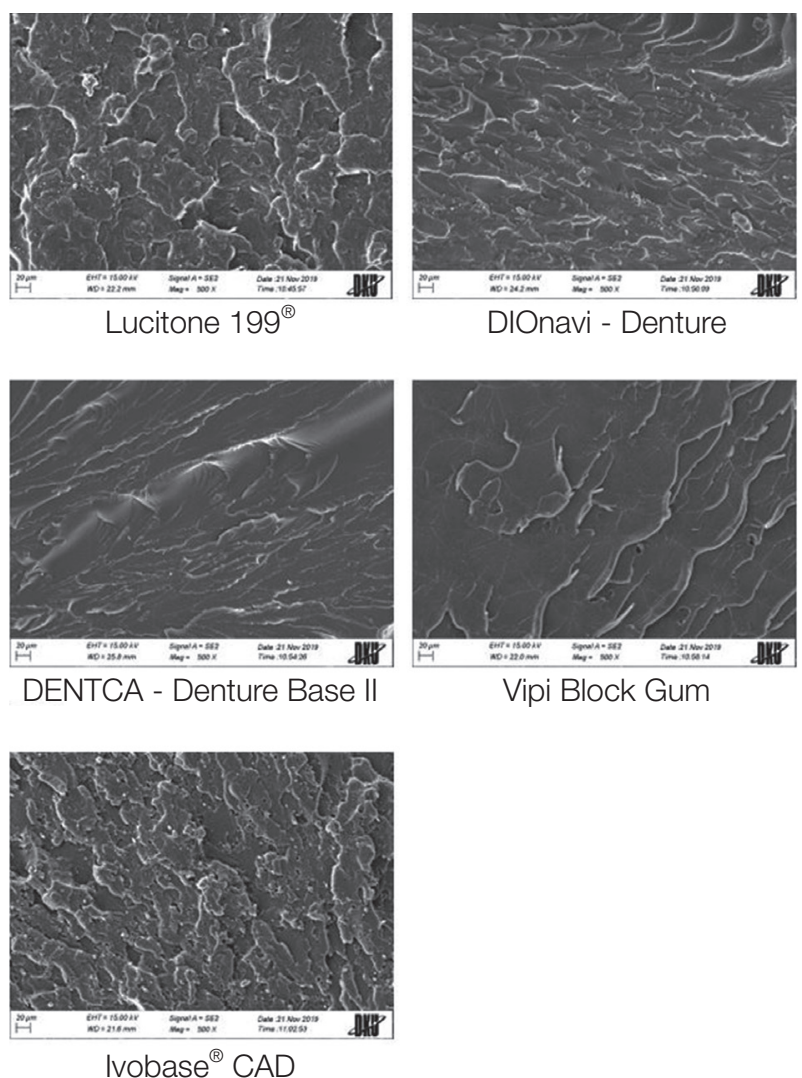

Fig. 4. Scanning electron microscope (SEM) image of the surfaces. Magnifications of $500 \times$.
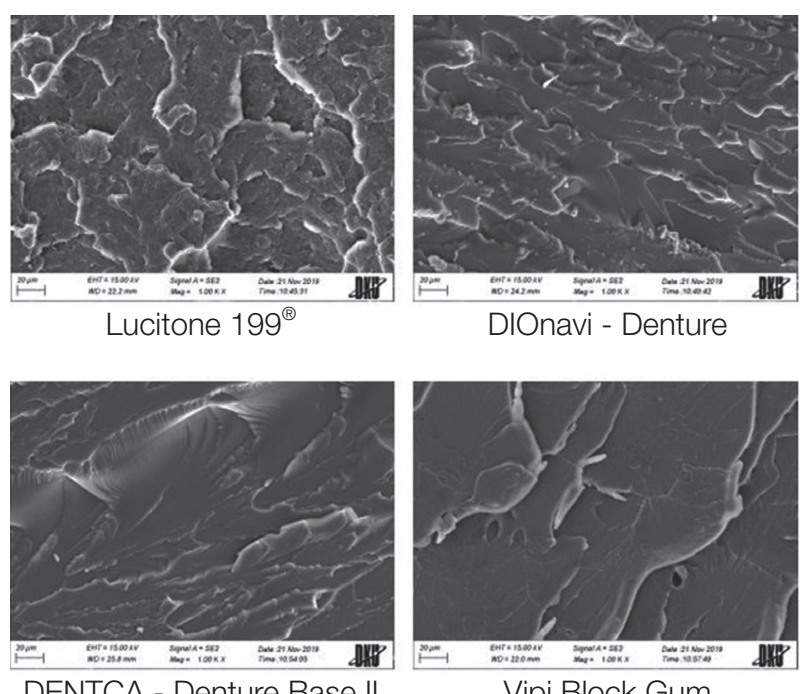

DENTCA - Denture Base II

Vipi Block Gum

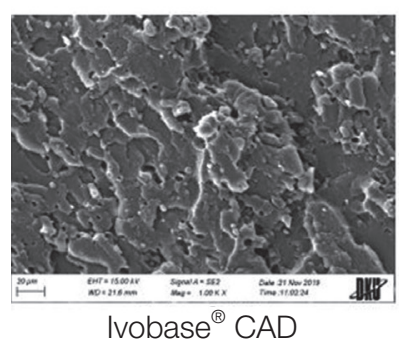

Fig. 5. Scanning electron microscope (SEM) image of the surfaces. Magnifications of $1000 \times$. 
the second null hypothesis was also partly rejected. M-VP showed a significant flexural strength difference compared to the conventional denture base resins. However, the other PMMA block, M-IV had significantly lower flexural strength than the conventional denture base resins. Most of the previous studies reported that PMMA denture base resins for milling have significantly higher flexural strength than conventional denture base resins. ${ }^{25-27}$ The study from Aguirre et al. ${ }^{25}$ used Lucitone $199^{\circledR}$ (Dentsply Sirona Inc.), as conventional denture base resins and Vertex PMMA (Avadent Original, Global Dental Science, Scottsdale, USA) as PMMA resins for milling. The average flexural strength of conventional denture base resins was $116.6 \pm 3.1(\mathrm{MPa})$ and $\mathrm{CAD} /$ CAM denture base resins' strength was $146.6 \pm 6.6$ (MPa). They described that CAD/CAM denture base resins have significantly higher flexural strength than conventional denture base resins. Furthermore, Al-Dwairi et al. ${ }^{26}$ used Meliodent (Heraeus Kulzer, Hanau, Germany) as conventional denture base resins and derived the average flexural strength as $93.33 \pm 8.64(\mathrm{MPa})$. Avadent PMMA pucks (Avadent Digital Dental Solutions, Scottsdale, USA) and Tizian Blank PMMA (Schütz Dental, Rosbach, Germany) were taken for CAD/CAM denture base resins. The average flexural strength of materials was $123.11 \pm$ $9.47(\mathrm{MPa})$ and $130.67 \pm 10.48(\mathrm{MPa})$ each. They concluded that CAD/CAM denture base resins have significantly higher flexural strength than conventional denture base resins.

According to Murakami et al. ${ }^{11}$ CAD/CAM denture base resins for milling are polymerized, especially with high pressure and temperature. This process reduces the residual monomers and the internal space and increases the average number of molecules of PMMA polymer, which leads to improved mechanical properties. ${ }^{11,24,28}$ The high flexural strength of CAD/CAM PMMA denture base resins for milling proved in this study and the other previous researches seems to have a strong connection with the conversion rate and void level characterized by its manufacturing process. Further, the components and the forms of PMMA chain are expected to be relevant with the flexural strength of CAD/CAM
PMMA resins.

However, Pacquet et al. ${ }^{29}$ reported the opposite result. They used Probase Hot (Ivoclar Vivadent Inc.) for conventional denture base resins and Ivobase ${ }^{\circledR}$ CAD (Ivoclar Vivadent Inc.) for CAD/CAM denture base resins for milling. The average flexural strengths were $97.31 \pm 4.96(\mathrm{MPa})$ and $87.98 \pm 7.37(\mathrm{MPa})$ each. They concluded that Ivobase ${ }^{\circledR}$ CAD has significantly lower flexural strength than the conventional denture base resins.

The differences of flexural strength among several types of CAD/CAM PMMA resin blocks were reported in the previous studies. ${ }^{24,28,30}$ These studies claim that the differences would be associated with different density or porosity caused by different manufacturing processes. Also, the difference in the components of CAD/CAM PMMA resin blocks would lead to the flexural strength difference. Aguirre et al. ${ }^{25}$ note that denture base resins classified as "Highimpact" resins include rubbery comonomers such as butyl acrylate that cause dispersion of rubber inclusion. M-IV are classified as a "High-impact" resins according to the manufacturer, "High-impact" resins can enhance its impact strength by its advanced elasticity, on the other hand, can impact negatively on the flexural strength. After analyzing the fractured patterns of specimens from the 3-point bend test, the specimens in the group of M-IV showed more transformations than other resins. Ductility and fractured patterns of M-IV seem to be related to its relatively low flexural strength.

Since there are almost no researches that investigate the flexural strength of $3 \mathrm{D}$ printing denture base resins, it is hard to compare with previous studies. In this study, P-DO did not show any significant flexural strength difference with the conventional denture base resins. However, P-DC had significantly lower flexural strength than the conventional denture base resins. These differences could be explained by the components of each material. P-DC contains diurethane dimethylacrylate (DUDMA) as monomers. According to the Safety Data Sheet (SDS) provided by the manufacturer, there is approximately $30-50$ percent of DUDMA in P-DC. Based on Gajewski et al. ${ }^{31}$ urethane dimethacrylate (UDMA) has low 
viscosity and high elasticity. UDMA is synthesized by the reactions from hydroxyalkyl methacrylates and diisocyanates. ${ }^{32}$ UDMA obtains elasticity and increases its conversion rate by hexaethylene diurethane. ${ }^{33,34}$ In the 3-point bend test of this study, it was observed that more transformations occur in P-DC before fracture. As mentioned before, the denture base resins with strong elasticity can have relatively low flexural strength.

This study also evaluated the changes in flexural strength depending on the thickness of denture base resins. Some materials showed a significant decrease in flexural strength as the thickness reduced. However, the average flexural strength of all groups was higher than $65 \mathrm{MPa}$, which is the minimum flexural strength suggested by ISO 20795-1:2013. If the thickness of denture base decreases, denture wearers would be more satisfied with reduced weight and increased retention. Also, when the interarch distance is restricted, dentures with lower thickness would be more useful. ${ }^{35}$

A limitation of this study is that the research regarding cyclic loading and fatigue resistance of a material against heat circulation are not covered. In addition to this, the specimens did not reflect the real shape of dentures. Also the actual dentures in the oral environment function more complicatedly, undergoing several types of strength in several directions. Furthermore, additional studies on the other mechanical properties such as impact strength, fracture toughness should be done.

\section{Conclusion}

The following conclusions can be drawn within the limitations of this study.

The flexural strength of different CAD/CAM denture base resins used in this study varied according to the composition and properties of each material.

The flexural strength of CAD/CAM denture base resins was higher than the standard suggested by ISO 20795-1:2013 at a thickness of $1.6 \mathrm{~mm}$ or more though the thickness decreased.

For clinical use of dentures with lower thickness, further researches should be done regarding other properties at lower thickness of denture base resins.

\section{ORCID}

Dong-Hyung Lee https://orcid.org/0000-0001-9798-7785

Joon-Seok Lee https://orcid.org/0000-0003-2962-1380

\section{References}

1. Zarb GA, Fenton AH. Prosthodontic treatment for edentulous patients. $13^{\text {th }}$ ed. St. Louis; Mosby/Elsevier; 2012. p. 133, 136, 140.

2. Anusavice KJ, Shen C, Rawls R. Phillips' science of dental materials. $12^{\text {th }}$ ed. Philadelphia; Saunders/ Elsevier; 2012. p. 94, 97, 480, 481, 483.

3. Ucar Y, Akova T, Aysan I. Mechanical properties of polyamide versus different PMMA denture base materials. J Prosthodont 2012;21:173-6.

4. Darbar UR, Huggett R, Harrison A. Denture fracture - a survey. Br Dent J 1994;176:342-5.

5. Sasaki H, Hamanaka I, Takahashi Y, Kawaguchi T. Effect of long-term water immersion or thermal shock on mechanical properties of high-impact acrylic denture base resins. Dent Mater J 2016;35: 204-9.

6. Kim SH, Watts DC. The effect of reinforcement with woven E-glass fibers on the impact strength of complete dentures fabricated with high-impact acrylic resin. J Prosthet Dent 2004;91:274-80.

7. Infante L, Yilmaz B, McGlumphy E, Finger I. Fabricating complete dentures with $\mathrm{CAD} / \mathrm{CAM}$ technology. J Prosthet Dent 2014;111:351-5.

8. John J, Gangadhar SA, Shah I. Flexural strength of heat-polymerized polymethyl methacrylate denture resin reinforced with glass, aramid, or nylon fibers. J Prosthet Dent 2001;86:424-7.

9. Huggett R, Bates JF, Packham DE. The effect of the curing cycle upon the molecular weight and properties of denture base materials. Dent Mater 1987;3:107-12.

10. El Ghazali S, Glantz PO, Strandman E, Randow $\mathrm{K}$. On the clinical deformation of maxillary complete dentures. Influence of denture-base design and shape of denture-bearing tissue. Acta Odontol Scand 1989;47:69-76. 
11. Murakami N, Wakabayashi N, Matsushima R, Kishida A, Igarashi Y. Effect of high-pressure polymerization on mechanical properties of PMMA denture base resin. J Mech Behav Biomed Mater 2013;20:98-104.

12. Kelly E. Fatigue failure in denture base polymers. J Prosthet Dent 1969;21:257-66.

13. Diaz-Arnold AM, Vargas MA, Shaull KL, Laffoon JE, Qian F. Flexural and fatigue strengths of denture base resin. J Prosthet Dent 2008;100:47-51.

14. Neihart TR, Li SH, Flinton RJ. Measuring fracture toughness of high-impact poly(methyl methacrylate) with the short rod method. J Prosthet Dent 1988;60:249-53.

15. Zappini G, Kammann A, Wachter W. Comparison of fracture tests of denture base materials. J Prosthet Dent 2003;90:578-85.

16. International Organization for Standardization. ISO 20795-1:2013. Dentistry - base polymers. Part 1: denture base polymers. Geneva: ISO;2015.

17. American Society for Testing and Materials International. ASTM D790. Standard test methods for flexural properties of unreinforced plastics and electrical insulating materials.

18. Gharechahi J, Asadzadeh N, Shahabian F, Gharechahi M. Flexural strength of acrylic resin denture bases processed by two different methods. J Dent Res Dent Clin Dent Prospects 2014;8:148-52.

19. Neumeier TT, Neumeier H. Digital immediate dentures treatment: a clinical report of two patients. J Prosthet Dent 2016;116:314-9.

20. Bidra AS, Taylor TD, Agar JR. Computer-aided technology for fabricating complete dentures: systematic review of historical background, current status, and future perspectives. J Prosthet Dent 2013;109:361-6.

21. Pereyra NM, Marano J, Subramanian G, Qeuk S, Leff D. Comparison of patient satisfaction in the fabrication of conventional dentures vs. DENTCA (CAD/CAM) dentures: A case report. J N J Dent Assoc 2015;86:26-33.

22. Goodacre CJ, Garbacea A, Naylor WP, Daher T, Marchack CB, Lowry J. CAD/CAM fabricated complete dentures: concepts and clinical methods of obtaining required morphological data. J Pros- thet Dent 2012;107:34-46.

23. Kydd WL. The comminuting efficiency of varied occlusal tooth form and the associated deformation of the complete denture base. J Am Dent Assoc 1960;61:465-71.

24. Steinmassl PA, Wiedemair V, Huck C, Klaunzer F, Steinmassl O, Grunert I, Dumfahrt H. Do CAD/ CAM dentures really release less monomer than conventional dentures? Clin Oral Investig 2017;21: 1697-705.

25. Aguirre BC, Chen JH, Kontogiorgos ED, Murchison DF, Nagy WWW. Flexural strength of denture base acrylic resins processed by conventional and CAD-CAM methods. J Prosthet Dent 2020;123: 641-6.

26. Al-Dwairi ZN, Tahboub KY, Baba NZ, Goodacre CJ. A comparison of the flexural and impact strengths and flexural modulus of CAD/CAM and conventional heat-cured polymethyl methacrylate (PMMA). J Prosthodont 2020;29:341-9.

27. Arslan M, Murat S, Alp G, Zaimoglu A. Evaluation of flexural strength and surface properties of prepolymerized CAD/CAM PMMA-based polymers used for digital 3D complete dentures. Int J Comput Dent 2018;21:31-40.

28. Steinmassl O, Offermanns V, Stöckl W, Dumfahrt $\mathrm{H}$, Grunert I, Steinmassl PA. In vitro analysis of the fracture resistance of CAD/CAM denture base resins. Materials (Basal) 2018;11:401.

29. Pacquet W, Benoit A, Hatège-Kimana C, Wulfman C. Mechanical properties of CAD/CAM denture base resins. Int J Prosthodont 2019;32:104-6.

30. McLaughlin JB, Ramos V Jr. Complete denture fabrication with $\mathrm{CAD} / \mathrm{CAM}$ record bases. J Prosthet Dent 2015;114:493-7.

31. Gajewski VE, Pfeifer CS, Fróes-Salgado NR, Boaro LC, Braga RR. Monomers used in resin composites: degree of conversion, mechanical properties and water sorption/solubility. Braz Dent J 2012;23:50814.

32. Peutzfeldt A. Resin composites in dentistry: the monomer systems. Eur J Oral Sci 1997;105:97-116.

33. Ruyter IE, Oysaed H. Composites for use in posterior teeth: Composition and conversion. J Biomed Mater Res 1987;21:11-23. 
34. Lee YS, Choi KK, Park SJ. Effect of resin matrix on degree of conversion and fracture toughness of dental composites. J Korean Acad Conserv Dent 2002;27:77-86.

35. Peng L, Chen L, Harris BT, Morton D, Lin WS. Managing complications resulting from limited prosthetic space with a monolithic, multichromatic CAD/CAM implant-retained overdenture. J Prosthet Dent 2017;118:712-6. 


\section{$\mathrm{CAD} / \mathrm{CAM}$ 의치상 레진과 열중합 의치상 레진의 두께에 따른 굴곡 강도 비교}

이동형 전공의, 이준석* 교수

단국대학교 치과대학 치과보철학교실

목적: 이 논문의 목적은 $\mathrm{CAD} / \mathrm{CAM}$ 의치상 레진과 열중합 의치상 레진의 굴곡 강도를 비교해보고, 두께에 따른 굴곡 강 도 변화도 비교해보는 것이다.

연구 재료 및 방법: 열중합 의치상 레진은 Lucitone $199^{\circledR}$ (C-LC)을 사용하였다. 3D printing 의치상 레진으로는 DIOnavi - Denture (P-DO)와 DENTCA - Denture Base II (P-DC)를 사용하였다. 밀링 PMMA 블록으로는 Vipi Block Gum (M-VP)과 M-IVoBase ${ }^{\circledR} \mathrm{CAD}(\mathrm{M}-\mathrm{IV})$ 를 사용하였다. 시편의 최종 규격은 $65.0 \mathrm{~mm} \times 12.7 \mathrm{~mm} \times 1.6 \mathrm{~mm} / 2.0 \mathrm{~mm} / 2.5$ $\mathrm{mm}$ 였다. 굴곡 강도와 굴곡 탄성율을 측정하기 위해 3점 굽힘 시험을 실시하였다. 그리고 파절된 시편의 단면을 주사전 자현미경 (SEM) 을 사용하여 분석하였다. 데이터의 정규성을 확인한 뒤 일원분산분석(one-way ANOVA)을 사용하여 유 의 수준 $P=0.05$ 로 설정하여 그룹 간의 차이를 평가한 뒤, 사후 분석을 위해 Tukey HSD test를 시행하였다.

결과: 동일 두께 내에서, $\mathrm{P}-\mathrm{DO}$ 를 제외한 나머지CAD/CAM 의치상 레진들과 열중합 의치상 레진의 굴곡 강도는 유의한 차이를 나타내었다. M-VP는 열중합 의치상 레진 보다 굴곡 강도가 높게 나타났고, P-DC와 M-IV는 낮은 굴곡 강도를 보였다. 굴곡 탄성률은 M-VP에서 제일 높게 나타났고 C-LC, P-DO, P-DC, M-IV 순으로 낮아졌으며 재료간에 모두 유 의한 차이가 나타났다. 두께에 따른 굴곡 강도는, C-LC에서는 $2.5 \mathrm{~mm}$ 가 $1.6 \mathrm{~mm}$ 보다 유의하게 높은 굴곡 강도를 보였고, P-DC, M-VP는 $2.5 \mathrm{~mm}$ 와 $2.0 \mathrm{~mm}$ 에서 $1.6 \mathrm{~mm}$ 보다 유의하게 높은 굴곡 강도가 나타났다. M-IV에서는 두께가 증가할수 록 유의한 굴곡 강도 증가가 나타났다. SEM 분석 결과 서로 다른 재료들의 파절된 단면은 각기 다른 양상을 띄었다.

결론: 본 연구에서 사용된 $\mathrm{CAD} / \mathrm{CAM}$ 의치상 레진의 굴곡 강도는 각 재료의 성분 및 특성에 따라 다양하게 나타났다. $\mathrm{CAD} / \mathrm{CAM}$ 의치상 레진의 굴곡 강도는 두께가 감소하여도 $1.6 \mathrm{~mm}$ 이상의 두께에서는 ISO 20795-1:2013에서 제시하 는 굴곡 강도보다 높게 나타났다. 하지만 보다 얇은 두께의 의치를 임상적으로 사용하기 위해서는, 더 낮은 두께의 의치 상 레진의 다른 특성들에 관한 추가적인 연구가 필요하다.

(구강회복응용과학지 2020;36(3):183-95)

주요어: $\mathrm{CAD} / \mathrm{CAM}$ 의치상 레진; 밀링용 PMMA 블록; 3D printing 의치상 레진; 굴곡 강도; 두께

*교신저자: 이준석

(31116)충청남도 천안시 동남구 단대로 119 단국대학교 치과대학 보철학교실

Tel: 041-550-0256 | Fax: 041-550-1975 | E-mail: joon322@dankook.ac. kr

|접수일: 2020년 7월 22일 | 수정일: 2020년 8월 6일 | 채택일: 2020년 8월 31일 